\section{Olfactory receptor-dependent receptor repression in Drosophila}

\author{
Kaan Mika ${ }^{1}$, Steeve Cruchet ${ }^{1}$, Phing Chian Chai ${ }^{1}$, Lucia L. Prieto-Godino ${ }^{1 \dagger}$, Thomas 0. Auer ${ }^{1}$, \\ Sylvain Pradervand ${ }^{1,2,3}$, Richard Benton ${ }^{1 *}$
}

In olfactory systems across phyla, most sensory neurons express a single olfactory receptor gene selected from a large genomic repertoire. We describe previously unknown receptor gene-dependent mechanisms that ensure singular expression of receptors encoded by a tandem gene array [Ionotropic receptor $75 c$ (Ir75C), Ir75b, and Ir75a, organized $5^{\prime}$ to $3^{\prime}$ ] in Drosophila melanogaster. Transcription from upstream genes in the cluster runs through the coding region of downstream loci and inhibits their expression in cis, most likely via transcriptional interference. Moreover, Ir75c blocks accumulation of other receptor proteins in trans through a protein-dependent, posttranscriptional mechanism. These repression mechanisms operate in endogenous neurons, in conjunction with cell type-specific gene regulatory networks, to ensure unique receptor expression. Our data provide evidence for inter-olfactory receptor regulation in invertebrates and highlight unprecedented, but potentially widespread, mechanisms for ensuring exclusive expression of chemosensory receptors, and other protein families, encoded by tandemly arranged genes.

\section{INTRODUCTION}

The selective neuronal expression of olfactory receptors is fundamental to the sensory representation of odors in the brain. All current models explaining singular receptor expression in vertebrates and invertebrates invoke the binding of transcriptional activators to one receptor locus while other receptor genes are silenced through transcriptional repressors and/or repressive chromatin structure (1-3). In invertebrates, this process is thought to rely only on deterministic, transcriptional "codes," where combinations of trans-acting factors function through modular, cis-regulatory elements of receptor genes to achieve specificity of neuronal expression (3-5). By contrast, mammalian olfactory receptor regulation also incorporates a feedback pathway, in which an expressed receptor protein prevents activation of other receptor genes via induction of the unfolded protein response that, ultimately, stabilizes the choice of the expressed receptor gene and precludes desilencing of other receptor loci $(1,2)$. In all animals, many olfactory receptor genes are found in tandem arrays, as a result of their duplication by nonallelic homologous recombination (6). In some cases in vertebrates, such clustered receptors share enhancer elements $(1,2)$, but whether this genomic organization has other consequences is unclear.

Here, we investigated the mechanisms ensuring the exclusive expression of members of a "model" cluster of three Drosophila melanogaster Ionotropic receptors (Irs), a gene family that encodes chemosensory receptors distantly related to ionotropic glutamate receptors (7-9). This gene array, $\operatorname{Ir} 75 c$, $\operatorname{Ir} 75 b$, and $\operatorname{Ir} 75 a$ (organized $5^{\prime}$ to $3^{\prime}$, spanning $<10 \mathrm{~kb}$ ) (Fig. $1 \mathrm{~A}$ ), is thought to have arisen through duplication of an Ir75a-like ancestral gene in the last common Drosophilidae ancestor (10). These genes encode volatile carboxylic acid-sensing "tuning" receptors that are expressed, together with the co-receptor Ir8a (11), in distinct, spatially stereotyped populations of olfactory sensory neurons (OSNs) housed in different

${ }^{1}$ Center for Integrative Genomics, Faculty of Biology and Medicine, University of Lausanne, CH-1015 Lausanne, Switzerland. ' ${ }^{2}$ Lausanne Genomic Technologies Facility, Faculty of Biology and Medicine, University of Lausanne, CH-1015 Lausanne, Switzerland. ${ }^{3}$ Vital-IT Group, Swiss Institute of Bioinformatics, CH-1015 Lausanne, Switzerland. *Corresponding author. Email: richard.benton@unil.ch

tPresent address: The Francis Crick Institute, London NW1 1BF, UK. sensory hairs (sensilla) in the main olfactory organ, the antenna (Fig. 1A) $(7,10,12)$.

\section{RESULTS}

RNAi screening for trans-acting regulators of $I r 75 c$, Ir75b, and Ir75a

To identify trans-acting factors that regulate the expression of $\operatorname{Ir} 75 c$, $\operatorname{Ir} 75 b$, and $\operatorname{Ir} 75 a$, we performed a transgenic RNA interference (RNAi) screen of 121 genes encoding transcription factors and chromatin regulators that were previously implicated in peripheral olfactory system development (13). We induced RNAi with a constitutive Gal4 driver that is active broadly throughout antennal development (Fig. 1B) (13) and examined expression of Ir75c, Ir75b, Ir75a, and Ir8a with antibodies, as well as overall antennal morphology.

Sixty-two genes exhibited RNAi phenotypes (Fig. 1C; fig. S1, $\mathrm{A}$ and $\mathrm{B}$; and tables $\mathrm{S} 1$ to $\mathrm{S} 3$ ): Most of the phenotypes reflect reductions in the number of OSNs expressing these tuning receptors, but increases in OSN population size were occasionally observed. RNAi of individual genes could affect the expression all three tuning receptors (and often also Ir8a), but many affected only one OSN type or different combinations of two neuron classes. These results revealed a complex and unique gene regulatory network for the three OSN populations.

Because RNAi is induced early in OSN development, many of the identified genes are likely to have upstream roles in antennal development and/or OSN fate specification; many lines produced morphological defects of the antenna (Fig. 1C, fig. S1B, and table S1). To identify candidate molecules that directly regulate receptor expression, we performed RNAi using two additional drivers, pebbled (peb)-Gal4 (14) and Ir8a-Gal4 (11), which are expressed $\sim 16$ hours after puparium formation (APF) and $\sim 48$ hours APF, respectively (Fig. 1B). As expected, only a subset of genes showed phenotypes with these drivers (Fig. 1, D and E, and tables S4 to S7). Notably, coexpression of Ir75c and Ir75b (which were visualized simultaneously) was extremely rare with any driver (table $\mathrm{S} 1$ ), suggesting that redundant mechanisms exist to prevent these receptors from being expressed in the same neuron. 
A

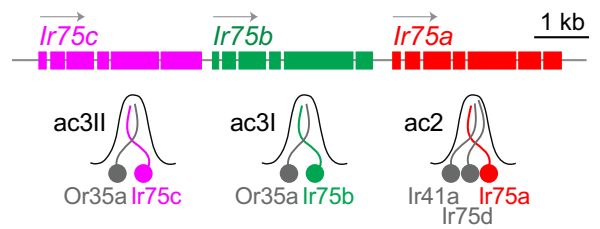

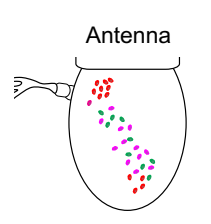

B

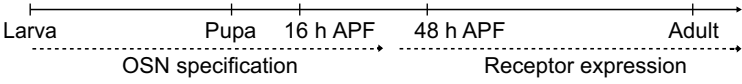

constitutive-Gal4

peb-Gal4

Ir8a-Gal4
C

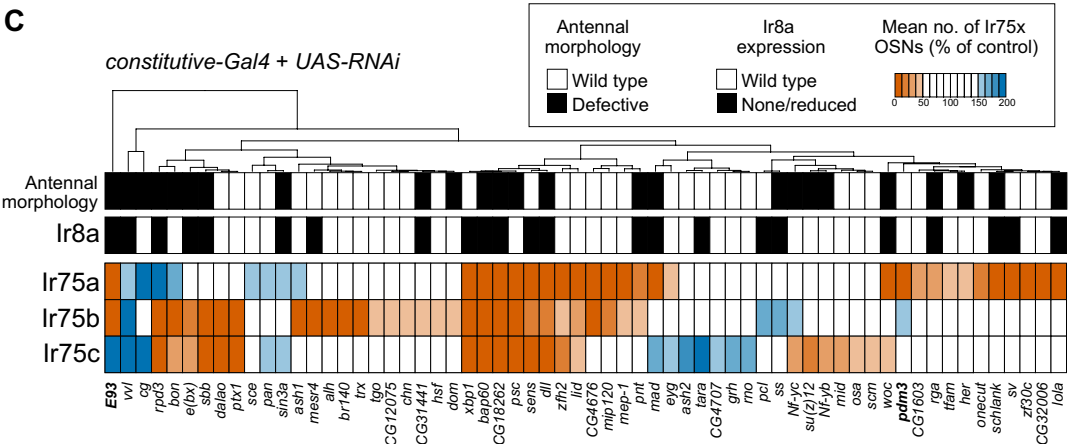

D

peb-Gal4 + UAS-RNAi

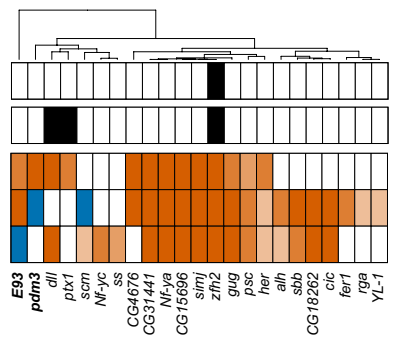

Ir8a-Gal4 + UAS-RNAi

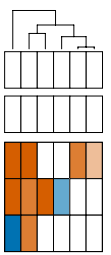

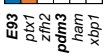

F

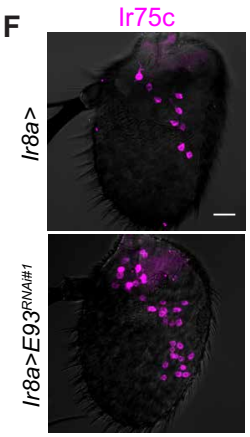

H

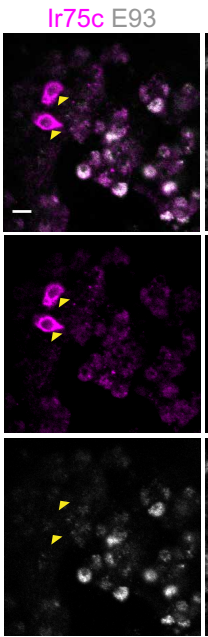

Ir75b

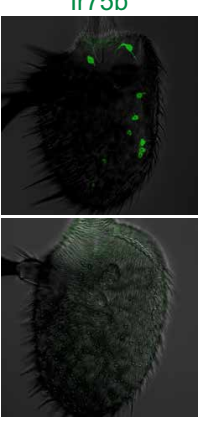

Ir75b>GFP E93
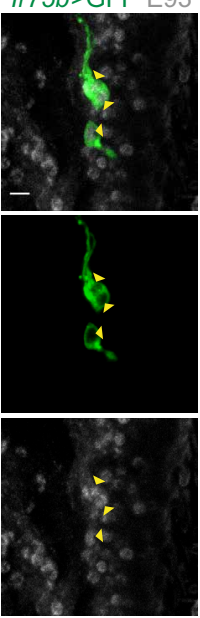

Ir75a

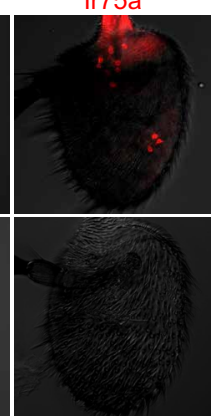

G

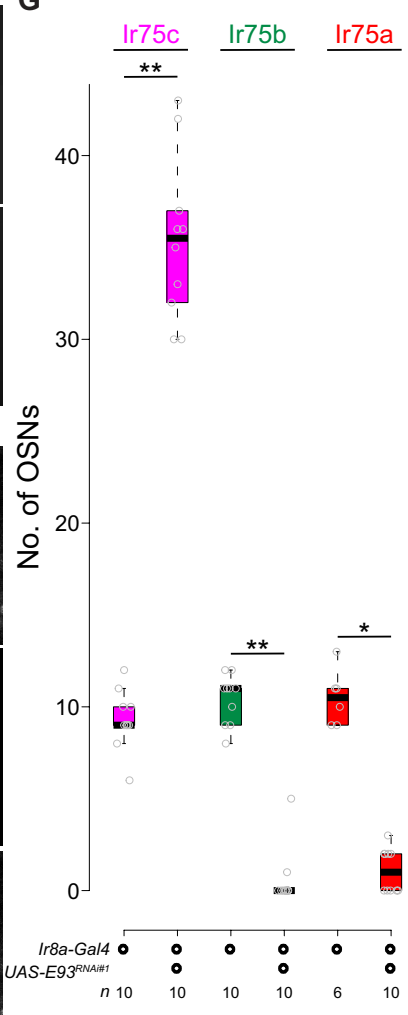

Ir75a E93

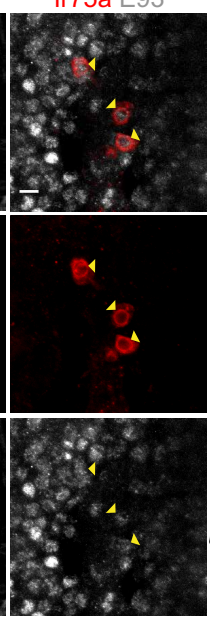

I

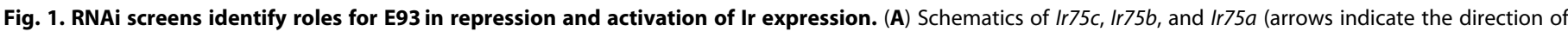

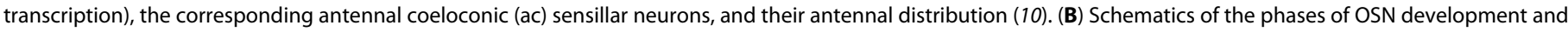

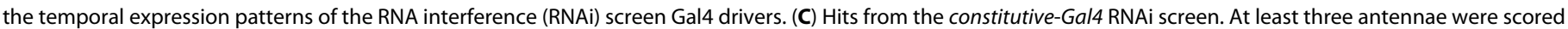

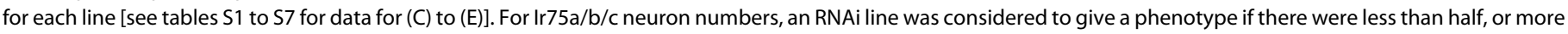

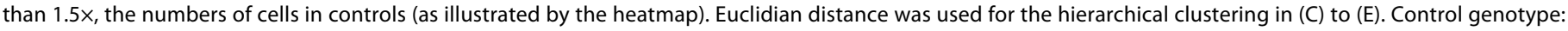

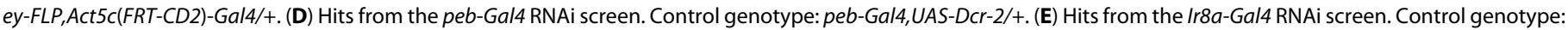

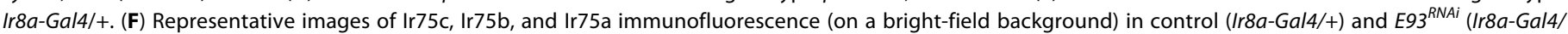

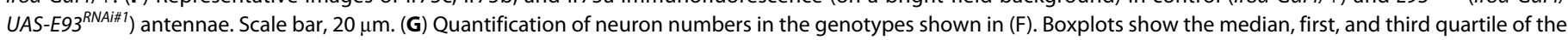

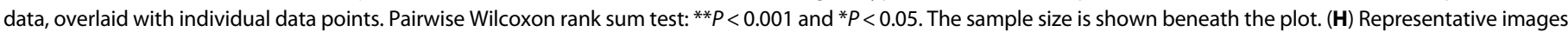

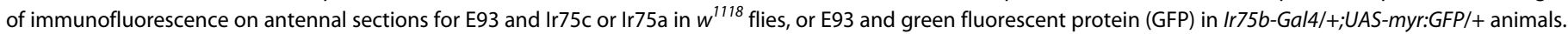

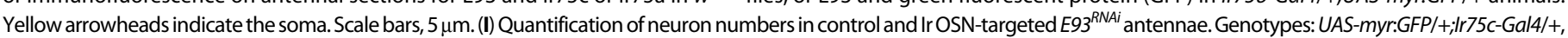

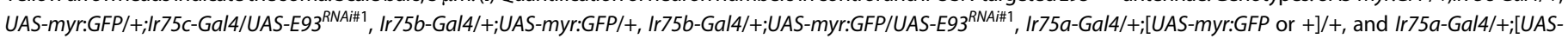
myr:GFP or + ]/UAS-E93 ${ }^{\text {RNAi\#1 }}$ (GFP signal was not used in any quantifications). Pairwise Wilcoxon rank sum test: ${ }^{* *} P<0.001$ and ${ }^{*} P<0.05$; NS, $P>0.05$. 


\section{E93 has a dual role in inhibition and activation of Ir expression}

From these screens, we first focused on Ecdysone-induced protein $93 F$ (E93) whose depletion produced a similar phenotype with all drivers: $E 93^{R N A i}$ animals display drastic loss of Ir75a and Ir75b expression, while Ir $75 \mathrm{c}$ is expressed in many additional neurons (Fig. 1, C to G). This phenotype was confirmed in two independent RNAi lines as well as in E93 mutant animals (fig. S2, A to C). While loss of Ir75a and Ir75b was consistently observed regardless of the driver, the number of Ir75c-expressing cells varied depending on the timing of knockdown (fig. S2A).

Previous studies showed that E93 is expressed broadly in the antenna and is necessary for the expression of several Odorant receptor (Or) genes (4). Colabeling with E93 and Ir antibodies [or an Ir transgenic reporter (10)] revealed that E93 is present in Ir75b and Ir75a neurons but not in Ir75c neurons (Fig. 1H). Ir8a-Gal4-driven $E 93^{R N A i}$ (hereafter, $\operatorname{Ir} 8 a>E 93^{R N A i}$ ) occurs at the time when tuning receptor transcription begins (15), suggesting that $\mathrm{E} 93$ has a very proximal (if not direct) role in regulating expression of these receptors. The number and spatial distribution of additional Ir75c-positive cells in $\operatorname{Ir} 8 a>E 93^{R N A i}$ antennae were consistent with Ir75b and Ir75a neurons expressing Ir75c instead of their normal receptors (Fig. 1, $\mathrm{A}, \mathrm{F}$, and G). We tested this possibility by inducing $E 93^{R N A i}$ with drivers for these individual neuron populations (Fig. 1I). $\operatorname{Ir} 75 a>E 93^{R N A i}$ led to loss of Ir75a expression and an increase in Ir75c OSN numbers. Ir $75 b>E 93^{R N A i}$ led to reduction (but not complete loss) of Ir75b expression and an increase in Ir75c OSN numbers. $\operatorname{Ir} 75 c>E 93^{R N A i}$ has little phenotypic consequence, consistent with the lack of E93 expression in this neuron population.

Together, these observations suggested an initial simple model: In Ir75a and Ir75b neurons, E93 promotes expression of Ir75a or Ir75b (presumably together with OSN subtype-specific transcription factors) and inhibits expression of Ir75c. In Ir75c neurons, E93 is absent, which permits expression of Ir75c (induced by other transcriptional activators).

\section{Ir75c-dependent repression of Ir75b and Ir75a expression}

In other tissues, E93 regulates local chromatin structure and/or directly controls gene transcription (16), raising the question of whether expression of $\operatorname{Ir} 75 c$, Ir75b, and $\operatorname{Ir} 75 a$ is affected at the transcriptional level by the absence of this protein. The boundaries of transcription units of these receptor genes were previously unclear, confounded by the detection of partial transcripts containing exons from adjacent members of this cluster (10). To clarify this issue and determine the effect of loss of E93 on transcription from these loci, we performed bulk RNA sequencing (RNA-seq) and quantitative reverse transcription polymerase chain reaction (qRT-PCR) of control and $E 93^{R N A i}$ antennae.

RNA-seq analysis of control tissue provided evidence for the existence of seven distinct transcripts encoded by these three receptor genes (Fig. 2A). Notably, many transcripts initiating from $\operatorname{Ir} 75 \mathrm{c}$ do not terminate at the $3^{\prime}$ end of this gene but rather run through the $I r 75 b$ and $I r 75 a$ exons. However, these transcripts are very unlikely to encode Ir75b or Ir75a proteins because they lack the first exon (containing the start codon) of the downstream genes (Fig. 2A). Similarly, most transcripts initiating from $\operatorname{Ir} 75 b$ incorporate exons 2 to 7 of $\operatorname{Ir} 75 a$ (Fig. 2A). These extended RNAs appear to reflect a failure in transcription termination at the $3^{\prime}$ end of $\operatorname{Ir} 75 c$ and $I r 75 b$, consistent with the absence of canonical transcription termination/ polyadenylation sequences downstream of their coding regions; such a sequence is only present $3^{\prime}$ of Ir75a (Fig. 2A). We confirmed the presence of such transcripts by analysis of Expressed Sequence Tag datasets and Sanger sequencing, as well as by RNA fluorescence in situ hybridization (FISH; see below and fig. S3).

We next examined changes in transcript levels for the three $I r$ genes in $E 93^{R N A i}$ antennae. Transcripts initiating from $\operatorname{Ir} 75 \mathrm{c}$ are highly up-regulated in the absence of E93 (Fig. 2, B and C), consistent with the ectopic expression of receptor protein (Fig. 1, F and G). Coding transcripts for $I r 75 b$ and $I r 75 a$ were identified as those containing the first exon of these genes: Transcription initiating from $I r 75 b$ is strongly diminished (Fig. 2, B and C), concordant with the loss of Ir75b expression (Fig. 1, F and G). By contrast, Ir75a transcript levels were only slightly, but nonsignificantly, reduced in $E 93^{R N A i}$ antennae (Fig. 2, $\mathrm{B}$ and $\mathrm{C}$ ), despite the loss of detectable Ir75a protein (Fig. 1, F and G). These observations refined our model as they indicate that E93 inhibits $\operatorname{Ir} 75 c$ transcription and promotes $\operatorname{Ir} 75 b$ transcription but has only an indirect role in promoting $\operatorname{Ir} 75 a$ expression.

We were unable to identify an E93 binding motif (16) within the minimal promoter element of $\operatorname{Ir} 75 b$ (10). Given the increase in $\operatorname{Ir} 75 c$ expression in Ir75b neurons (Fig. 1I) and the existence of transcriptional read-through across these loci (Fig. 2A), we hypothesized that the decrease in $\operatorname{Ir} 75 b$ transcription is an indirect consequence of the ectopic expression of $\operatorname{Ir} 75 c$ through a process of transcriptional interference (17), i.e., where transcription from one gene (here, $\operatorname{Ir} 75 c$ ) inhibits, in cis, the expression of a downstream gene (here, $\operatorname{Ir} 75 b$ ).

To test this possibility, we obtained an $\operatorname{Ir} 75 \mathrm{c}$ mutant $\left(\operatorname{Ir} 75 c^{\mathrm{MB08510}}\right.$ ) bearing a Minos insertion in the $5^{\prime}$ regulatory region (fig. S3A), which we found leads to essentially complete loss of $\operatorname{Ir} 75 c$ RNA (fig. S3, B to D). By contrast, transcripts of $\operatorname{Ir} 75 b$ and $\operatorname{Ir} 75 a$ were still detected (fig. S3C). Moreover, analysis of the number of neurons detected by RNA probes for these receptor genes in control and $\operatorname{Ir} 75 \mathrm{c}$ mutants provided further evidence of read-through of $\operatorname{Ir} 75 c$ transcripts through these downstream loci (fig. S3, C and D). We noticed that numbers of Ir75b (and Ir75a) neurons were slightly elevated in $I r 75 c$ mutant antennae compared to controls (Fig. 2, D and E); we return to this phenomenon in the last section of the results. Most notably, combination of the $\operatorname{Ir} 75 \mathrm{c}$ mutant with $E 93^{R N A i}$ was sufficient to restore Ir75b expression (Fig. 2, D and E). This result has two implications: first, that $\mathrm{E} 93$ is not directly required for transcription of $\operatorname{Ir} 75 b$ and, second, that expression of $\operatorname{Ir} 75 c$ can inhibit transcription of $\operatorname{Ir} 75 b$

Loss of $\operatorname{Ir} 75 \mathrm{c}$ in an $E 93^{R N A i}$ background also led to restoration of Ir75a expression (Fig. 2, D and E). As Ir75a is still robustly transcribed in $E 93^{R N A i}$ antennae (Fig. 2, B and C), this observation indicates that Ir $75 \mathrm{c}$ inhibits I $75 \mathrm{a}$ expression predominantly posttranscriptionally (although the existence of $I r 75 c b a$ transcripts raises the possibility of a minor, cis-acting effect of $\operatorname{Ir} 75 c$ on $\operatorname{Ir} 75 a$ transcription). We also noted that Ir75b expression is only very slightly increased in $E 93^{R N A i}$ antennae in a heterozygous $\operatorname{Ir} 75 c$ mutant, where one allele of $\operatorname{Ir} 75 b$ should not be subject to transcriptional interference by $\operatorname{Ir} 75 c$ (Fig. 2E). We found no evidence that $I r 75 c$ inhibits $I r 75 b$ transcription through interchromosomal regulation (i.e., transvection) (fig. S4) (18), suggesting that Ir75b must be additionally repressed posttranscriptionally by $\operatorname{Ir} 75 \mathrm{c}$.

\section{Posttranscriptional repression of Ir75a and Ir75b by Ir75c protein}

We examined the hypothesized posttranscriptional inhibitory activity of $\operatorname{Ir} 75 c$ by misexpressing the gene from a transgenic cDNA 
A

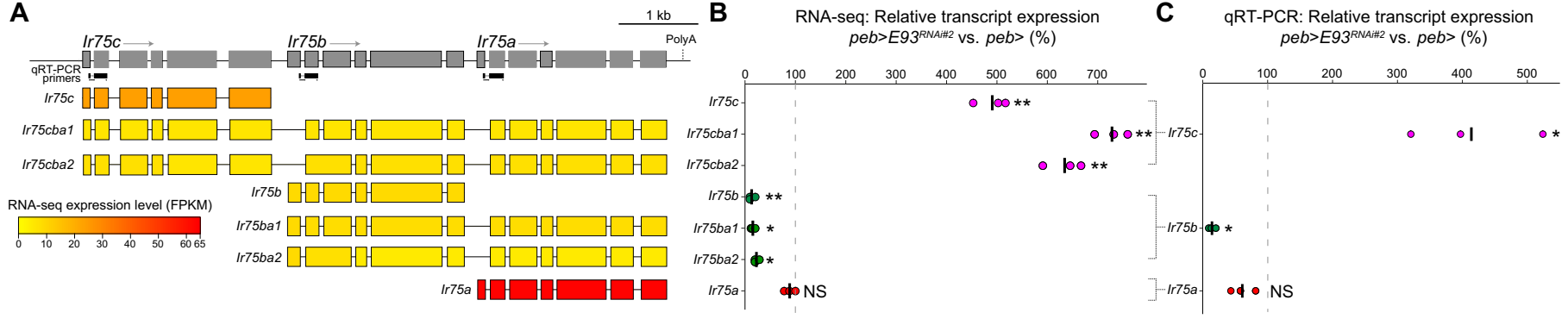

B RNA-seq: Relative transcript expression

C qRT-PCR: Relative transcript expression $p e b>E 93^{\text {RNAHA }}$ vs. peb> $(\%)$ $p e b>E 93^{\text {RNA Iit }}$ vs. $p e b>(\%)$

D

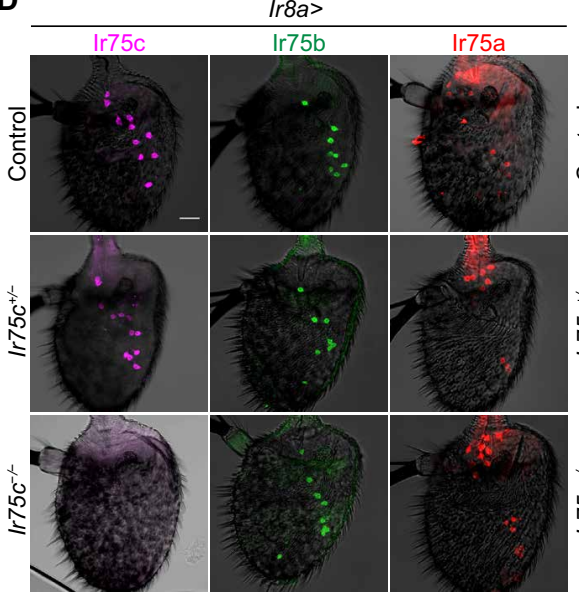

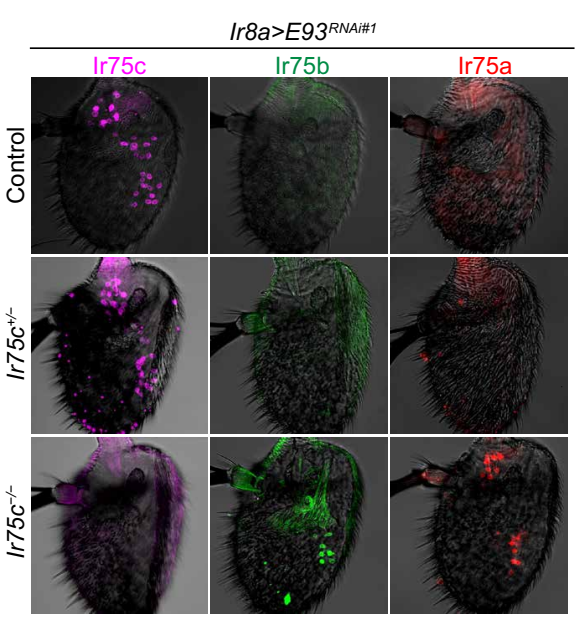

E

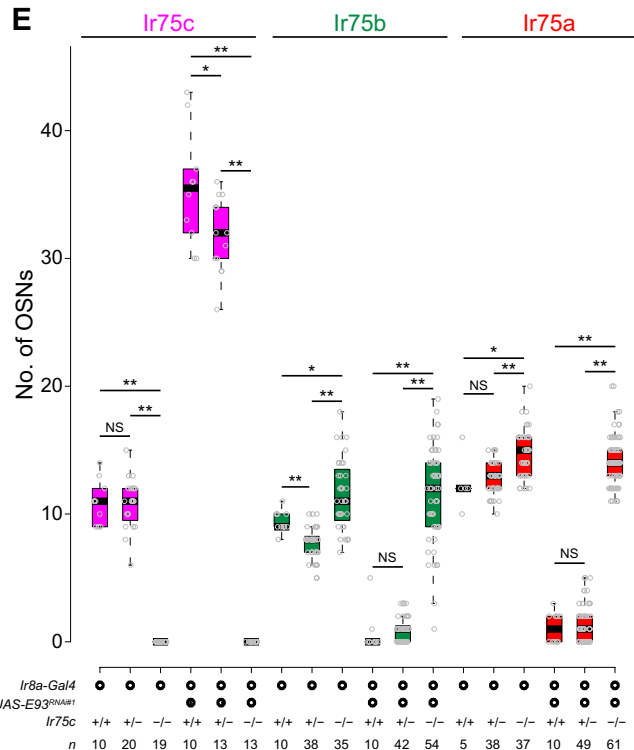

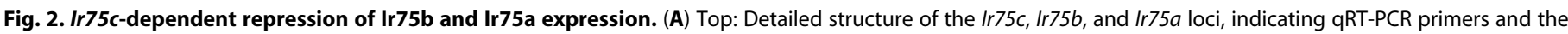

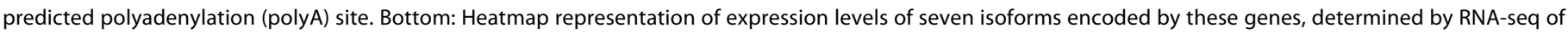

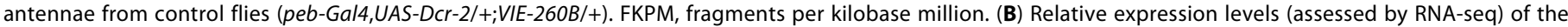

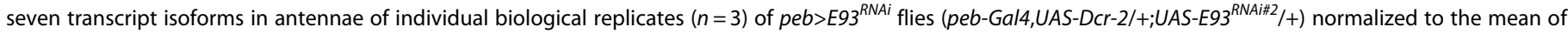

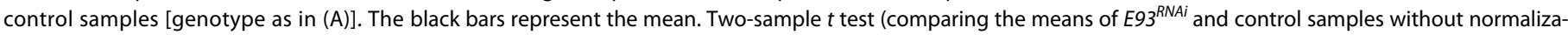

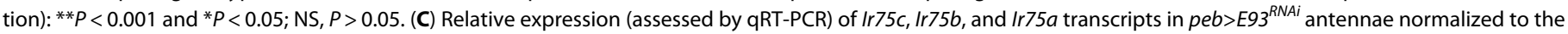

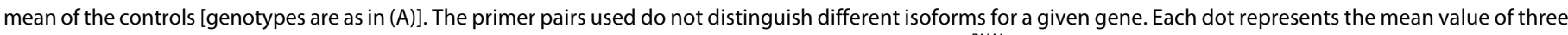

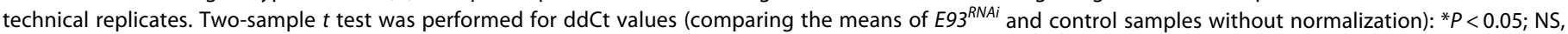

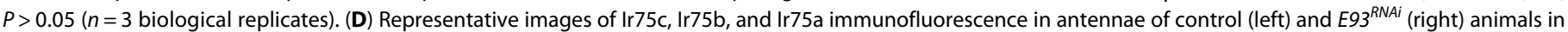

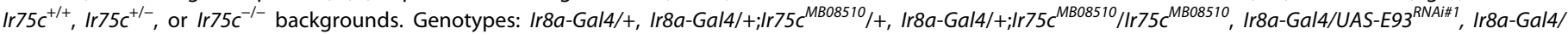

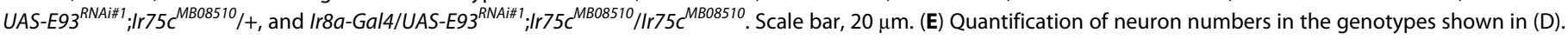
Pairwise Wilcoxon rank sum test and $P$ values adjusted for multiple comparisons with the Benjamini and Hochberg method: ${ }^{*} P<0.001$ and ${ }^{*} P<0.05 ;$ NS, $P>0.05$.

construct (i.e., unlinked to the endogenous $\operatorname{Ir} 75 \mathrm{c}$ locus) using $\operatorname{Ir} 8 a$ Gal4. We observed a mild but significant reduction in the number of Ir75b-expressing cells and more substantial loss of Ir75a (Fig. 3, A and B). Many of the detectable Ir75b and Ir75a neurons had only weak immunofluorescence signals (Fig. 3C). As a control, we misexpressed Ir $75 a$ cDNA using the same driver, but this had no obvious impact on Ir75c expression, and led to a slight but variable increase in Ir75b (Fig. 3, A to C).

To test whether the inhibitory effect of Ir75c expression was at the RNA or protein level, we replaced the start codon in the $\operatorname{Ir} 75 \mathrm{c}$ cDNA with a stop codon ( $\left.\operatorname{Ir} 75 c^{A T G>T G A}\right)$. Ir $8 a$-Gal4-driven expression of this transgene led to ectopic $\operatorname{Ir} 75 c$ RNA, but not ectopic Ir75c protein (Fig. 3D). In these antennae, no reduction in Ir75b or Ir75a expression was observed, contrasting with the impact of the protein-coding transgene (Fig. 3, D to F). These data, together with the analysis of Ir transcript levels (Fig. 2, B and C), suggest a model in which transcription from the endogenous $\operatorname{Ir} 75 \mathrm{c}$ gene inhibits Ir $75 b$ at the transcriptional level, and Ir75c protein impairs Ir75b and Ir75a expression posttranscriptionally.

\section{Ir75b-dependent, cis-mediated repression of Ir75a}

The failure of $\operatorname{rr} 75 b$ transcripts to terminate efficiently at the $3^{\prime}$ end of this gene (Fig. 2A) raised the possibility that $\operatorname{Ir} 75 b$ can also suppress expression of $\operatorname{Ir} 75 a$ by transcriptional interference, analogous to the inhibition of $\operatorname{Ir} 75 b$ transcription by $\operatorname{Ir} 75 c$. From our RNAi screen, we noted that both constitutive-Gal4- and peb-Gal4-driven RNAi of pou domain motif 3 ( $p d m 3$ ) led to increased numbers of Ir75b-expressing cells and greatly diminished the number of Ir75aexpressing cells (Ir75c expression is unchanged) (Fig. 1, C and D). An independent study of $\mathrm{Pdm} 3$ (19) indicated that this transcription factor is expressed in Ir75a neurons, but not Ir75b or Ir75c OSNs; here, Pdm 3 promotes Ir75a neuron fate and suppresses Ir75b neuron 
A

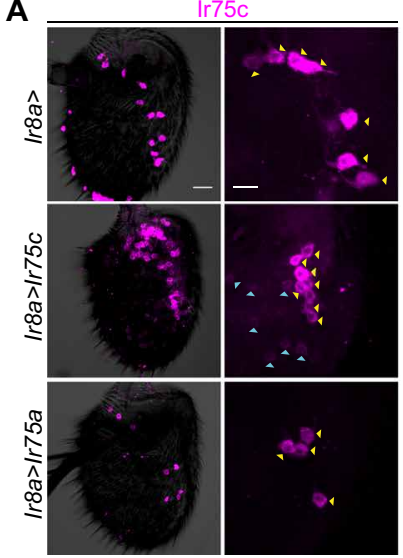

D

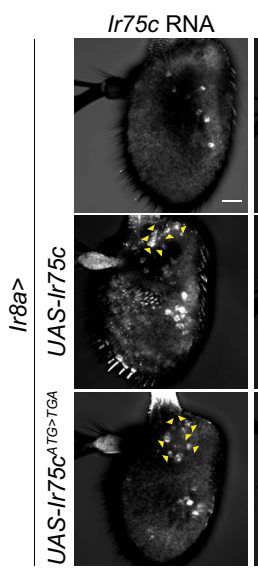

$\operatorname{lr} 75 \mathrm{~b}$

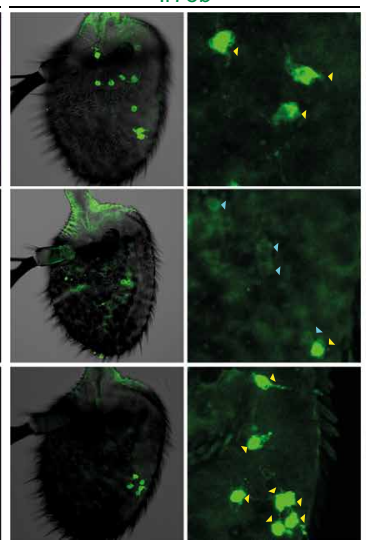

Ir75a

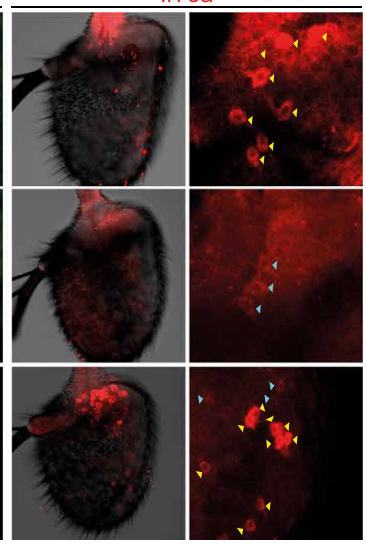

B

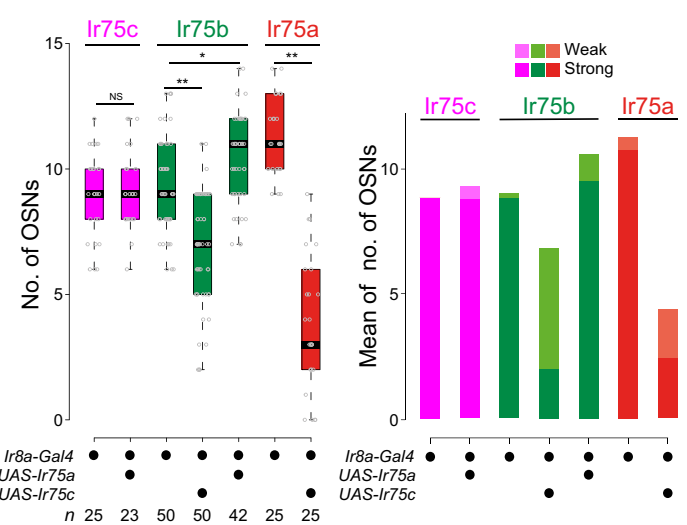

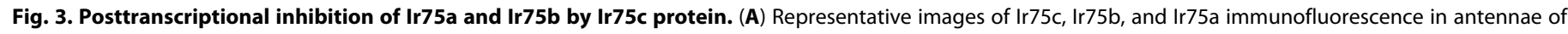

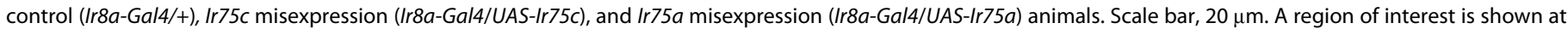

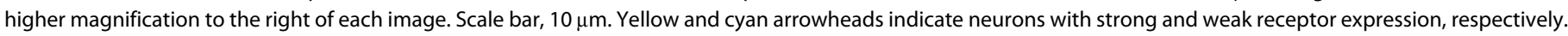

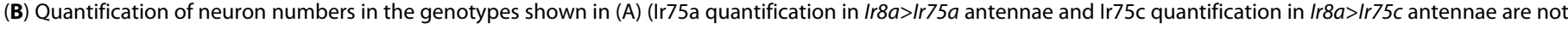

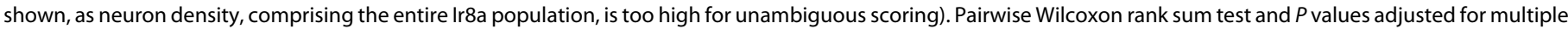

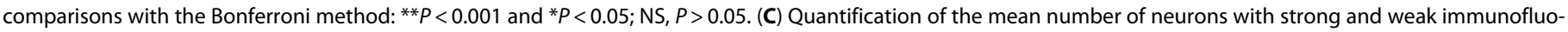

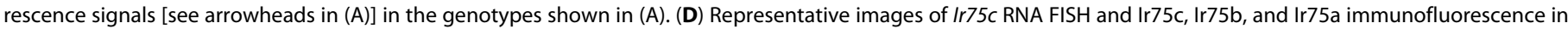

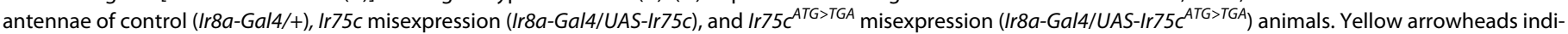

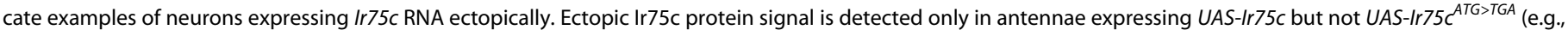

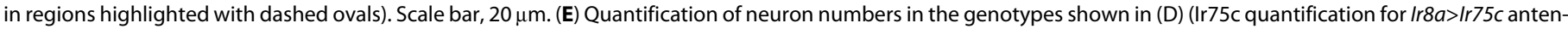

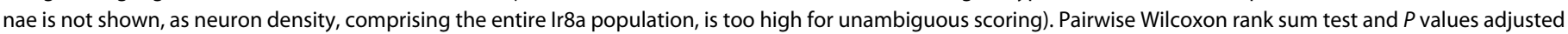

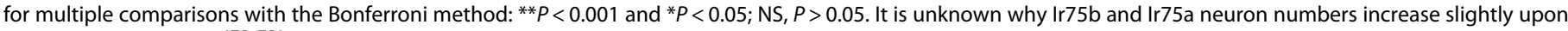
expression of UAS-Ir75 $C^{A T G>T G A}$. (F) Quantification of the number of neurons with strong and weak immunofluorescence signals in the genotypes shown in (D).

fate, encompassing receptor protein expression and axon targeting properties (19). We wondered, however, whether loss of Ir75a in $p d m 3^{R N A i}$ antennae might be an indirect consequence of ectopic Ir75b expression.

We first examined whether loss of $p d m 3$ affects transcription of these genes. Results from qRT-PCR analysis corresponded well with changes in the number of neurons expressing Ir75b and Ir75a proteins: $p e b>p d m 3^{R N A i}$ antennae displayed an increase in $\operatorname{Ir} 75 b$ transcription and decreased $\operatorname{Ir} 75 a$ transcription (fig. S5A). Furthermore, we confirmed by RNA FISH the increase in number of cells expressing Ir75b transcripts upon loss of Pdm 3 (fig. S5, B and C). The number of neurons detected by our $\operatorname{Ir} 75 a$ probe was not different between genotypes, presumably because this reagent detects transcripts initiating from all three genes in the cluster; the decrease in Ir75a-expressing cells is therefore counterbalanced by the increase in the size of the Ir75b neuron population (fig. S5, B and C).

To test whether Pdm3's role in promoting Ir75a transcription was direct or indirect, we combined $p e b>p d m 3^{R N A i}$ with an $\operatorname{Ir} 75 b$ mutant $\left(\operatorname{Ir} 75 b^{D s R e d}\right)$, which bears a $1.3-\mathrm{kb}$ insertion in the middle of the gene that disrupts $\operatorname{Ir} 75 b$ transcription and abolishes Ir75b protein expression (fig. S3, A, E, and F, and Fig. 4, A and B). Ir75a expression is partially restored through loss of one copy of $\operatorname{Ir} 75 b$ and fully restored in homozygous $\operatorname{Ir} 75 b$ mutants (Fig. 4, A and B). Together, these data support a model in which Pdm3 functions in 
A

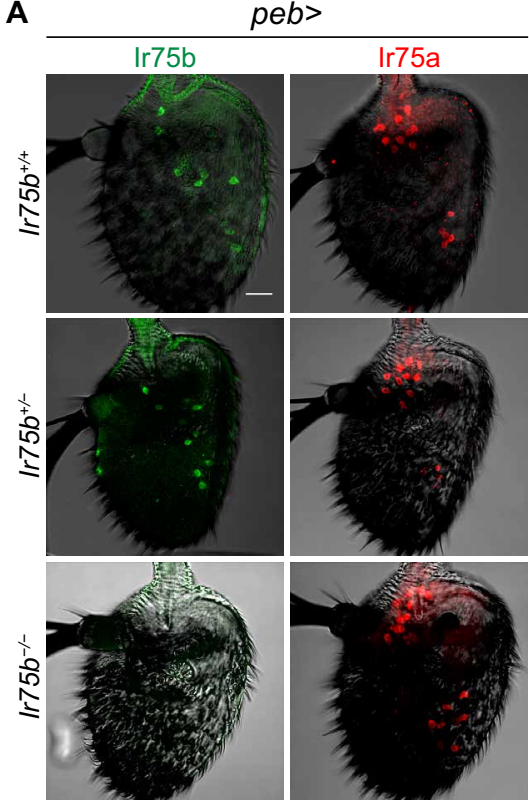

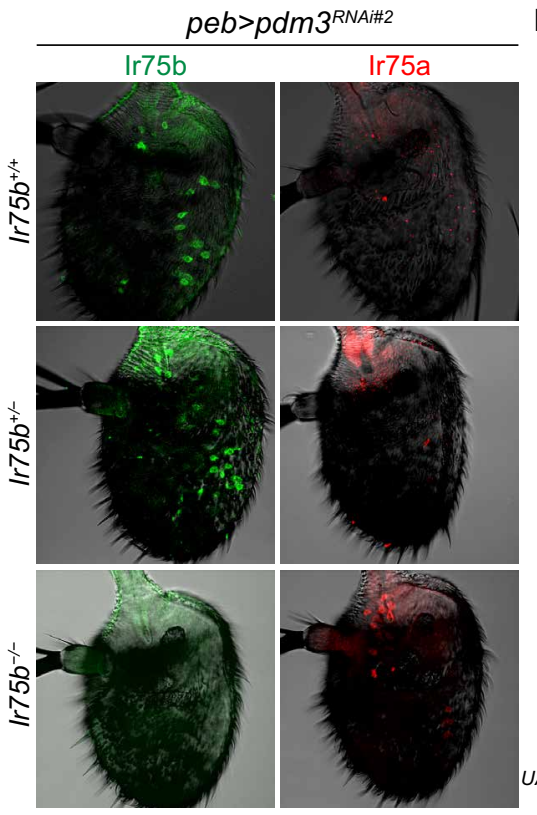

B

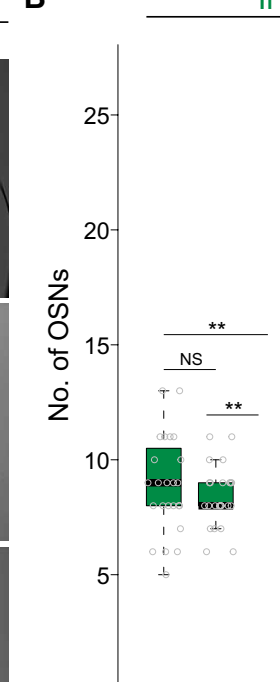

$\operatorname{lr} 75$

$75 b$

$\operatorname{Ir} 75 a$
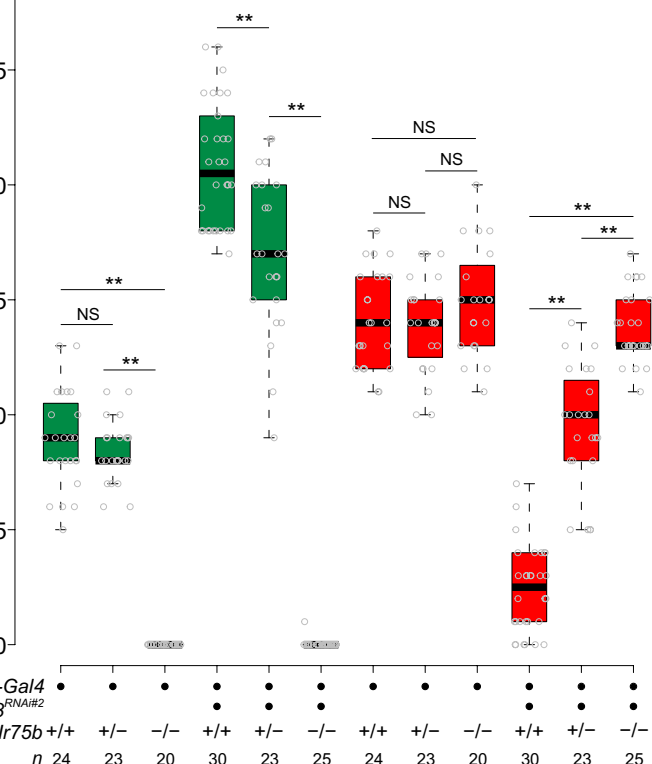

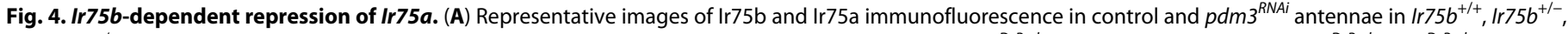

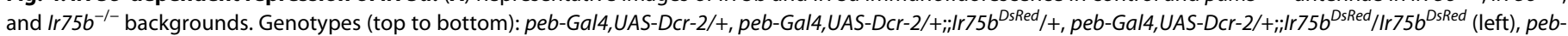

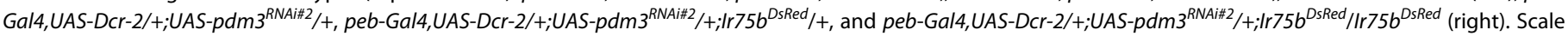

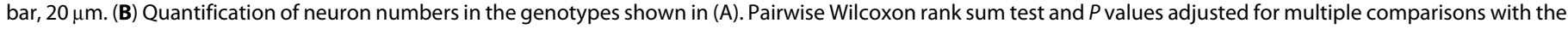
Bonferroni method: ${ }^{*} P<0.001 ; \mathrm{NS}, P>0.05$.

Ir75a neurons to repress $\operatorname{Ir} 75 b$ expression, which would otherwise inhibit transcription of Ir75a in cis. We tested whether Ir75b might also affect Ir75a expression posttranscriptionally but found that heterologous expression of a UAS-Ir75b transgene yielded barely detectable ectopic Ir75b, precluding conclusive insights.

\section{Ir75c suppresses expression of Ir75b and Ir75a in its own neurons}

Last, we asked whether Ir75c and Ir75b exert a repressive effect on other genes in the cluster in their endogenous neurons and not only when expressed ectopically in other neurons (i.e., in $E 93^{R N A i}$ or $p d m 3^{R N A i}$ antennae or through transgenic misexpression of $\operatorname{Ir} 75 \mathrm{c}$ ). In $\operatorname{Ir} 75 \mathrm{c}$ mutant antennae, we observed a small and variable increase in the number of neurons expressing Ir75b and Ir75a, compared to controls (Fig. 5, A and B; see also Fig. 2E). Similarly, in $\operatorname{Ir} 75 b$ mutants, we observed an increase in numbers of neurons expressing Ir75a, but no effect on those expressing Ir75c, consistent with a contribution of Ir75b in suppressing expression of Ir75a in its own neurons (Fig. 5, A and B). This latter effect was sensitive to the genetic background, however, as we did not observe such an increase in all genotypes (e.g., Fig. 4B).

We therefore focused on the $\operatorname{Ir} 75 \mathrm{c}$ mutant and examined whether the additional expression of Ir75b and Ir75a is in Ir75c neurons, by labeling these cells transgenically with $\operatorname{Ir} 75 c>$ RedStinger. In control tissue, we detected, as expected, no expression of Ir75a or Ir75b in Ir75c neurons (with the exception of one cell) (Fig. 5, C and D). By contrast, in Ir $75 c$ mutants, several Ir $75 c>$ RedStinger-labeled neurons expressed one or other of these Irs (Fig. 5, C and D), indicating that Ir75c represses these receptors in its own neural population. It is not unexpected that the ectopic expression of Ir75b and
Ir75a is limited to only a small subset of $\operatorname{Ir} 75 c$ mutant neurons as these cells presumably only partially resemble the gene regulatory environment of endogenous Ir75b or Ir75a neurons, as illustrated by our original RNAi screens (Fig. 1, C to E).

\section{DISCUSSION}

Through a screen for trans-acting regulators controlling the expression of a model tandem cluster of olfactory receptor genes, we have found, serendipitously, novel types of feedback pathway to ensure exclusive receptor expression. These findings provide evidence for inter-olfactory receptor regulation in invertebrates (Fig. 6).

The cis-mediated transcriptional repression of $\operatorname{Ir} 75 b$ by $\operatorname{Ir} 75 c$, and of $\operatorname{Ir} 75 a$ by $\operatorname{Ir} 75 b$, is most simply explained by transcriptional interference (Fig. 6) (17). This model is supported by the existence of transcripts containing exons from adjacent genes within this array and the presence of a canonical transcription terminator sequence downstream of only Ir75a. Our previous mapping of RNA polymerase II occupancy in these neurons by Targeted DamID (19) provides further evidence for the failure in efficient termination of the transcription machinery at the $3^{\prime}$ end of $\operatorname{Ir} 75 c$ and $\operatorname{Ir} 75 b$. The biochemical mechanism of transcriptional interference is not fully understood but is thought to result from steric competition on the DNA, where RNA polymerase II complexes transcribing an upstream gene prevent assembly of the transcription machinery at the promoter of a downstream gene $(17,20)$. Testing this model explicitly would require the ability to terminate RNA polymerase II transcription at the $3^{\prime}$ end of $\operatorname{Ir} 75 c$ and $\operatorname{Ir} 75 b$. As such, we cannot currently exclude alternative (or additional) mechanisms to explain the reduced transcription of the downstream gene when the upstream 
A

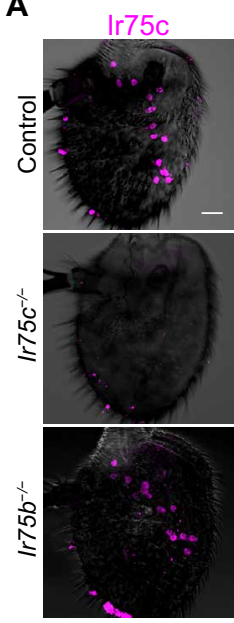

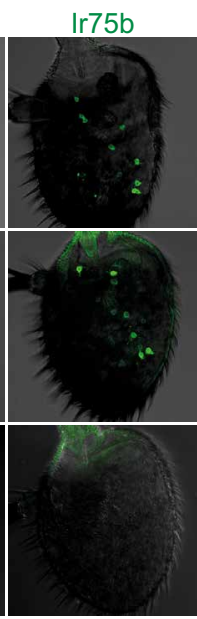

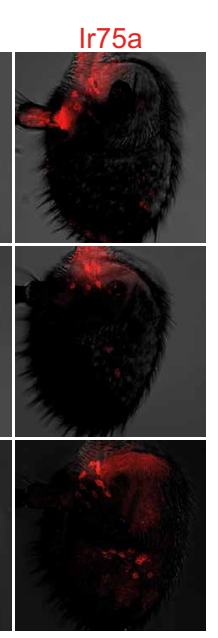

B

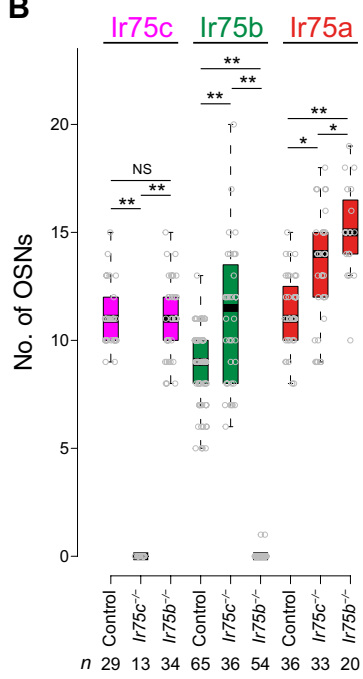

C

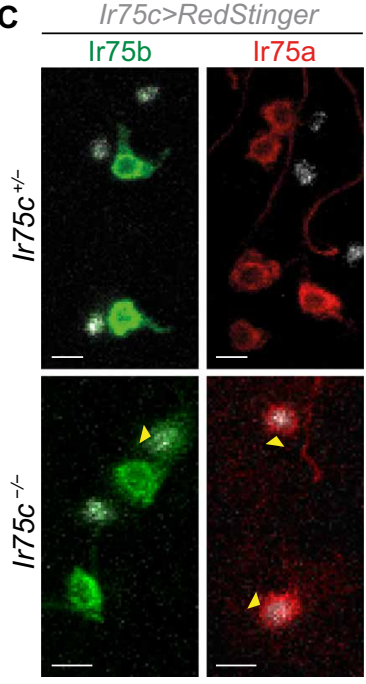

D

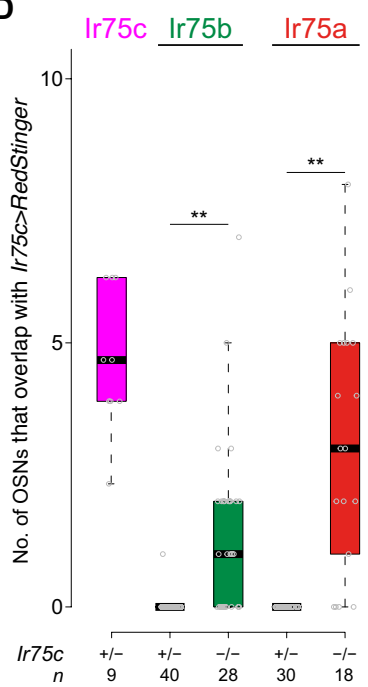

Fig. 5. Ectopic expression of Ir75b and Ir75a in Ir75c mutant neurons. (A) Representative images of Ir75c, Ir75b, and Ir75a immunofluorescence in control ( ${ }^{1118}$ ), $1 r 75 c^{-1-}\left(I r 75 c^{M B 08510} / I r 75 c^{M B 08510}\right)$, and $/ r 75 b^{-/-}\left(I r 75 b^{D s R e d} / / r 75 b^{D s R e d}\right)$ antennae. Scale bar, $20 \mu \mathrm{m}$. (B) Quantification of neuron numbers in the genotypes shown in (A). Pairwise Wilcoxon rank sum test and $P$ values adjusted for multiple comparisons with the Benjamini and Hochberg method: ${ }^{* *} P<0.001$ and ${ }^{*} P<0.05 ;$ NS, $P>0.05$. (C) Representative images of Ir75b and Ir75a immunofluorescence for a subset of Ir75c neurons [labeled with RedStinger (gray)] in $I r 75 c^{+/-}$and $I r 75 c^{-/-}$antennae. Yellow arrow-

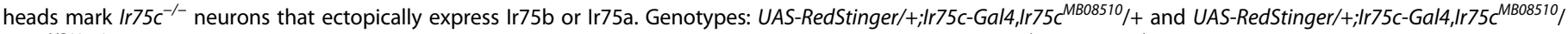
$\operatorname{Ir} 75 \mathrm{c}^{\mathrm{MB08510}}$. Scale bars, $5 \mu \mathrm{m}$. (D) Quantification of Ir75c neurons that ectopically express Ir75b or Ir75a in $1 \mathrm{r} 75 \mathrm{c}^{+/-}$and Ir75 $\mathrm{c}^{-/-}$flies [genotypes as in (C)]. Pairwise Wilcoxon rank sum test and $P$ values adjusted for multiple comparisons with the Bonferroni method: ${ }^{* *} P<0.001$. In the control Ir 75 c immunofluorescence samples, all neurons $[81$ of $81(100 \%)$ ] express both Ir75c and $I r 75 c>$ RedStinger. Ectopic expression of Ir75b and Ir75a in $I r 75 c^{-/-}$neurons appeared to be mutually exclusive [only 1 of 18 (5.5\%) neurons expressed both of these receptors, presumably, in part, due to the repressive effect of Ir75b expression on Ir75a (Fig. 4)].
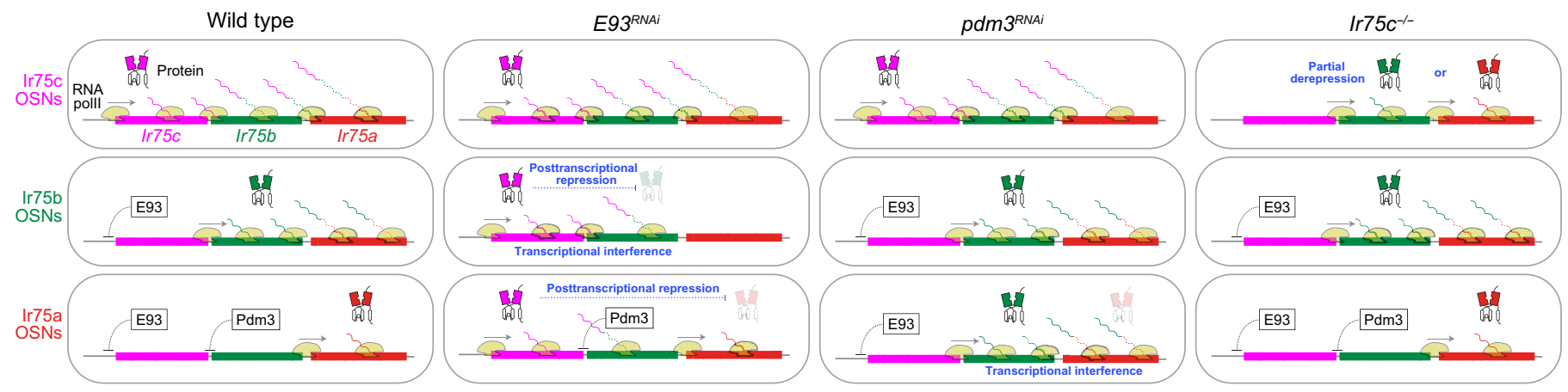

Fig. 6. Model of the regulatory interactions between $I r 75 c$, Ir75b, and $I r 75 a$. Schematics of the predicted interactions between $I r 75 c$, Ir75b, and $I r 75 a$ gene products in each neuron class in wild-type, $E 93^{R N A i}, p d m 3^{R N A i}$, and $/ r 75 c^{-/-}$genetic backgrounds. RNA polymerase II complexes (RNA pollI) are shaded yellow. Protein-coding transcripts and long 3' untranslated region extensions (lacking the first exons of the downstream genes) are shown as unbroken and broken lines, respectively. It is unknown whether E93 and Pdm3 inhibit transcription of Ir75c and Ir75b, respectively, directly or indirectly (indicated by dashed lines). Pdm3 is selectively expressed in Ir75a neurons (19).

gene is active, such as competition during promoter selection; investigating this possibility will depend on much better knowledge of the transcriptional regulatory sequences of each gene (10). However, we do not find any evidence for interchromosomal regulation (transvection) between these loci.

Similar to the Irs analyzed in this work, several Gustatory receptor (Gr) genes are arranged in clusters in Drosophila, with transcription termination signals only apparent after the last gene in the array (21). Analysis of transcripts encoded by the tandem sugar-sensing Gr genes revealed that they encompass exons of several individual loci (21-23). While polycistronic transcription of these genes might underlie the neuronal coexpression observed for some of these receptors (21-23), an alternative (or additional) possibility is that such a pattern of transcription reflects a mechanism by which $\mathrm{Gr}$ genes inhibit each other's expression through transcriptional interference. Future analysis of this and other tandem arrays of chemosensory receptor genes will reveal how widespread the phenomenon is. In an evolutionary context, the existence of cis-mediated transcriptional repression in recently duplicated chemosensory genes may provide a substrate for natural selection to favor rapid acquisition of distinct expression patterns (or otherwise pseudogenization of one duplicate). Such a possibility was supported by genome-wide expression analysis of nested (nonchemosensory) genes in drosophilids (24). For the Irs studied here, recruitment of E93 and Pdm3 
to their gene regulatory networks may have introduced important inhibitory connections: By preventing transcription of upstream genes in the cluster, these transcription factors permit expression of downstream genes (Fig. 6).

The mechanism of posttranscriptional (trans) suppression by Ir75c protein of Ir75b and, in particular, Ir75a remains unclear. As Ir $75 a$ transcription is not substantially diminished by $\operatorname{Ir} 75 \mathrm{c}$ misexpression, it seems unlikely that this inhibition operates via the same feedback mechanism between mammalian olfactory receptor loci, which ensures the silenced transcriptional state of nonchosen receptor genes (2). The repression of $\operatorname{Ir} 75 a$ by Ir75c also appears to be distinct from the exclusion mechanism between Rhodopsin 5 (Rh5) and Rh6 in the Drosophila visual system, in which an Rh6 protein-dependent signal represses $r h 5$ promoter activity (25), as well as the broad suppression of $O r$ transcription resulting from transgenic overexpression of one Or in Anopheles gambiae (26). One possibility is that Ir protein subunits compete with each other for the binding to the common Ir8a co-receptor, which is essential for their stabilization in OSNs $(11,27)$. Precise details of the repression mechanism(s) will require future development of methods to quantify the processes controlling the translation of receptor transcripts and regulating the turnover of proteins within specific OSN populations.

Given the widespread occurrence of chemosensory receptor gene families in arrays in the genomes of most or all animals (6), our discoveries may have broad implications for the evolution of their distinct expression patterns. Moreover, the dominance of expression of 5'-located Ir genes over $3^{\prime}$-located genes is reminiscent of the "posterior dominance" and "posterior prevalence" of transcripts and proteins encoded by clustered Hox transcription factor genes $(28,29)$. Study of the regulatory interactions between arrays of olfactory receptor genes may reveal general insights into how other types of proteins encoded by tandemly duplicated genes evolve distinct expression patterns.

\section{MATERIALS AND METHODS \\ Drosophila strains and culture}

Flies were maintained at $25^{\circ} \mathrm{C}$ in 12 -hour light:12-hour dark conditions, except where noted. D. melanogaster strains were maintained on a standard wheat flour-yeast-fruit juice medium. Published mutant and transgenic D. melanogaster are described in table S8. For histological experiments, flies were 3 to 8 days old. To increase the efficiency of RNAi, flies were moved to $27^{\circ} \mathrm{C}$ after 2 to 3 days. As peb $>E 93^{\text {RNAi\#1 }}$ flies were not viable at $27^{\circ} \mathrm{C}$, this genotype was raised at $19^{\circ} \mathrm{C}$.

\section{New Drosophila strains UAS-Ir75 ${ }^{\text {ATG }>\text { TGA }}$ transgenic line}

Site-directed mutagenesis of the Ir $75 c$ start codon in $p U A S T-I r 75 c$ attB (10) was performed using a primer pair (CGATTTCCAC A C C T GA A C T A G T T G G C C A T T G / C A A T G G C CAACTAGTTCAGGTGTGGAAATCG; the introduced stop codon is underlined) using standard methods. The presence of the mutation was confirmed by sequencing, and the mutated $\operatorname{Ir} 75 \mathrm{c}$ cDNA was subcloned into a new $p U A S T$ attB vector backbone to avoid other, unintended mutations in the construct, before transgenesis via the phiC31 site-specific integration system (landing site attP40) by BestGene Inc.

\section{Ir75b mutant}

The sgRNA expression vector was generated by cloning an annealed primer pair (GTCGCCCTCAGTGGCTGACGCGCC/AAACGGCGCGTCAGCCACTGAGGG) into Bbs I-digested $p C F D 3-d U 6-3 g R N A$ (Addgene, no. 49410), as previously described (30). The donor vector was constructed by amplifying Ir75b-specific homology arms (1.1 to $1.4 \mathrm{~kb})$ from genomic DNA of $\{$ Act5C-Cas9.P.RFP- $\} Z H-2 A$ DNAlig4[169] flies (31) [homology arm 1 (5' to $\left.3^{\prime}\right)$ : GATCCACCTGCGATCTCGCCACCTCGAAGCAGAGCCGGT/GATCCACCTGCGATCCTACCGGCCTGGTAACCCAATCTA; homology arm 2: GATCGCTCTTCGTATGCGTCAGCCACTAAGGGATATGTT/GATCGCTCTTCGGACCACGGCCACCGTGTGATTATGCTG] and inserting the resultant products into pHD-DsRed-attP (Addgene, no. 51019) (32) via Aar I/Sap I restriction enzyme-based cloning.

Transgenesis of $D$. melanogaster was performed in-house following standard protocols (http://gompel.org/methods). For CRISPRCas9-mediated homologous recombination, we injected a mix of the

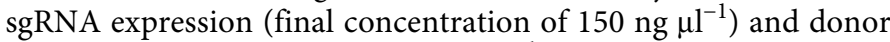
vector (final concentration of $400 \mathrm{ng} \mathrm{\mu l}^{-1}$ ) into \{Act5C-Cas9.P.RFP-\} ZH-2A DNAlig4[169] flies. Ir75b mutant animals were selected on the basis of DsRed expression, and correct integration was confirmed by PCR. The $\operatorname{Ir} 75 b^{\text {DsRed }}$ allele was outcrossed to $w^{1118}$ for three generations before establishment of a homozygous mutant stock.

\section{Histology and image analysis}

Immunofluorescence and RNA FISH on whole-mount antennae or antennal cryosections were performed essentially as previously described (33). Primary and secondary antibodies used are listed in table S9. Guinea pig anti-Ir75c antibodies were raised against the same peptide epitope (KEYLSELHLRPRLQHRMD) as used to generate the rabbit anti-Ir75c antibodies (10) and affinity-purified by Proteintech Group Inc. RNA FISH probes complementary to sequences of $\operatorname{Ir} 75 a, \operatorname{Ir} 75 b$, and $\operatorname{Ir} 75 c$ were as previously described (10). Imaging was performed on a Zeiss confocal microscope LSM710 or, for RNA FISH samples, a Zeiss confocal microscope 880 Airyscan, using $40 \times$ or $63 \times$ oil immersion objectives. All images were processed in Fiji, and the cell counter plugin was used to quantify neuron numbers.

\section{RNA-seq and analysis}

Antennal RNA was extracted from three biological replicates of control [peb-Gal4,UAS-Dcr-2/+;VIE-260B/+ (VIE-260B is an empty landing site used for RNAi transgene insertion)] and $E 93^{R N A i}$ (pebGal4,UAS-Dcr-2/+;UAS-E93 ${ }^{R N A i \# 2} /+$ ) animals. For each pair of biological replicates, $\sim 350$ females were grown under identical conditions and antennae were harvested and RNA was extracted from 2- to 5-day-old flies in parallel, as previously described (13). RNA quality was assessed on a Fragment Analyzer (Advanced Analytical Technologies Inc.); all RNAs had an RNA quality number of 9 to 10. mRNA isolation, RNA-seq library preparation, and sequencing were performed as previously described (34).

Reads were aligned against $D$. melanogaster.BDGP6.92 genome using STAR (Spliced Transcripts Alignment to a Reference) v2.5.3a (35). The reads mapped to the region $3 \mathrm{~L}: 17,815,000-17,823,000$ containing the $\operatorname{Ir} 75 c / \operatorname{Ir} 75 b / \operatorname{Ir} 75 a$ genes were extracted using SAMtools v1.8 (36), and transcripts were assembled using StringTie v1.3.3b (37) with parameters for stranded library and a minimum transcript length of 1000 bases. Transcript abundance was quantified with StringTie 
using the D. melanogaster.BDGP6.92 reference annotation complemented with the four novel isoforms (options: $-\mathrm{G},-\mathrm{m} 1000$, -e, and -B).

\section{Quantitative reverse transcription polymerase chain reaction}

For analysis of $E 93^{R N A i}$ animals, the same RNA samples were used as for the RNA-seq experiment. For other experiments, RNA was isolated from 2- to 5-day-old flies ( 50 antennae) with the QIAGEN RNeasy Mini Kit (catalog no. 74104), and cDNA was prepared using Invitrogen SuperScript II Reverse Transcriptase (catalog no. 18064022).

qRT-PCR was performed on the ABI 7500 Real-Time PCR System (Applied Biosystems, Foster City, CA) using iQ SYBR Green Supermix from Bio-Rad. Primer pairs $\left(5^{\prime}\right.$ to $\left.3^{\prime}\right)$ were as follows: Ir75c (TGCTGGTCCATAAAGGAGGC/GGCTTTGTCGCAACCCAAAT), Ir75b (ATTTTGCACTGCTCACTTTCGC/ AACTGTACCACTTTTGTCGCA), Ir75a (GCTGGCAGAGTGATGAAAGTCT/TCCTGAGTCTGATCGCACTTT), and control (tubulin: $\alpha$ Tub84B isoform) (TGTCGCGTGTGAAACACTTC/ AGCAGGCGTTTCCAATCTG). qRT-PCR was performed with three technical replicates for each of three biological replicates for each primer pair. The mean of the three technical replicates was used for each biological replicate. ddCt values were calculated with normalization to tubulin values.

\section{Statistical analysis}

Statistical analyses and plotting were performed in RStudio v3.5.2 (R Foundation for Statistical Computing, Vienna, Austria, 2005; R-project-org). For multiple comparisons, a two-tailed Wilcoxon rank sum test was performed followed by the Benjamini and Hochberg method or the Bonferroni method for $P$ value adjustment. For fig. S5A, $P$ values were calculated by one-way analysis of variance (ANOVA) test of ddCt values followed by a Tukey's post hoc test for multiple comparisons. For other qRT-PCR experiments and for the RNA-seq analysis, $P$ values were calculated by a two-sample $t$ test.

\section{SUPPLEMENTARY MATERIALS}

Supplementary material for this article is available at http://advances.sciencemag.org/cgi/ content/full/7/32/eabe3745/DC1

View/request a protocol for this paper from Bio-protocol.

\section{REFERENCES AND NOTES}

1. M. H. Nagai, L. M. Armelin-Correa, B. Malnic, Monogenic and monoallelic expression of odorant receptors. Mol. Pharmacol. 90, 633-639 (2016).

2. R. P. Dalton, S. Lomvardas, Chemosensory receptor specificity and regulation. Annu. Rev. Neurosci. 38, 331-349 (2015).

3. S. Barish, P. C. Volkan, Mechanisms of olfactory receptor neuron specification in Drosophila. Wiley Interdiscip. Rev. Dev. Biol. 4, 609-621 (2015).

4. S. Jafari, L. Alkhori, A. Schleiffer, A. Brochtrup, T. Hummel, M. Alenius, Combinatorial activation and repression by seven transcription factors specify Drosophila odorant receptor expression. PLoS Biol. 10, e1001280 (2012).

5. S. H. Fuss, A. Ray, Mechanisms of odorant receptor gene choice in Drosophila and vertebrates. Mol. Cell. Neurosci. 41, 101-112 (2009).

6. M. Nei, Y. Niimura, M. Nozawa, The evolution of animal chemosensory receptor gene repertoires: Roles of chance and necessity. Nat. Rev. Genet. 9, 951-963 (2008).

7. R. Benton, K. S. Vannice, C. Gomez-Diaz, L. B. Vosshall, Variant ionotropic glutamate receptors as chemosensory receptors in Drosophila. Cell 136, 149-162 (2009).

8. R. Rytz, V. Croset, R. Benton, lonotropic receptors (IRs): Chemosensory ionotropic glutamate receptors in Drosophila and beyond. Insect Biochem. Mol. Biol. 43, 888-897 (2013).

9. L. Ni, The structure and function of ionotropic receptors in Drosophila. Front. Mol. Neurosci. 13, 638839 (2020).

10. L. L. Prieto-Godino, R. Rytz, S. Cruchet, B. Bargeton, L. Abuin, A. F. Silbering, V. Ruta, M. Dal Peraro, R. Benton, Evolution of acid-sensing olfactory circuits in drosophilids. Neuron 93, 661-676.e6 (2017).
11. L. Abuin, B. Bargeton, M. H. Ulbrich, E. Y. Isacoff, S. Kellenberger, R. Benton, Functional architecture of olfactory ionotropic glutamate receptors. Neuron 69, 44-60 (2011).

12. L. L. Prieto-Godino, R. Rytz, B. Bargeton, L. Abuin, J. R. Arguello, M. D. Peraro, R. Benton, Olfactory receptor pseudo-pseudogenes. Nature 539, 93-97 (2016).

13. P. C. Chai, S. Cruchet, L. Wigger, R. Benton, Sensory neuron lineage mapping and manipulation in the Drosophila olfactory system. Nat. Commun. 10, 643 (2019).

14. T. Komiyama, L. B. Sweeney, O. Schuldiner, K. C. Garcia, L. Luo, Graded expression of semaphorin-1 a cell-autonomously directs dendritic targeting of olfactory projection neurons. Cell 128, 399-410 (2007).

15. H. Li, T. Li, F. Horns, J. Li, Q. Xie, C. Xu, B. Wu, J. M. Kebschull, C. N. McLaughlin, S. S. Kolluru, R. C. Jones, D. Vacek, A. Xie, D. J. Luginbuhl, S. R. Quake, L. Luo, Single-cell transcriptomes reveal diverse regulatory strategies for olfactory receptor expression and axon targeting. Curr. Biol. 30, 1189-1198.e5 (2020).

16. C. M. Uyehara, S. L. Nystrom, M. J. Niederhuber, M. Leatham-Jensen, Y. Ma, L. A. Buttitta, D. J. McKay, Hormone-dependent control of developmental timing through regulation of chromatin accessibility. Genes Dev. 31, 862-875 (2017).

17. K. E. Shearwin, B. P. Callen, J. B. Egan, Transcriptional interference-A crash course. Trends Genet. 21, 339-345 (2005).

18. T. Fukaya, M. Levine, Transvection. Curr. Biol. 27, R1047-R1049 (2017).

19. J. R. Arguello, L. Abuin, J. Armida, K. Mika, P. C. Chai, R. Benton, Targeted molecular profiling of rare olfactory sensory neurons identifies fate, wiring, and functional determinants. eLife 10, e63036 (2021).

20. N. J. Proudfoot, Transcriptional termination in mammals: Stopping the RNA polymerase II juggernaut. Science 352, aad9926 (2016).

21. J. Slone, J. Daniels, H. Amrein, Sugar receptors in Drosophila. Curr. Biol. 17, 1809-1816 (2007).

22. A. Dahanukar, Y. T. Lei, J. Y. Kwon, J. R. Carlson, Two Gr genes underlie sugar reception in Drosophila. Neuron 56, 503-516 (2007).

23. S. Fujii, A. Yavuz, J. Slone, C. Jagge, X. Song, H. Amrein, Drosophila sugar receptors in sweet taste perception, olfaction, and internal nutrient sensing. Curr. Biol. 25, 621 (2015).

24. R. Assis, Transcriptional interference promotes rapid expression divergence of Drosophila nested genes. Genome Biol. Evol. 8, 3149-3158 (2016).

25. D. Vasiliauskas, E. O. Mazzoni, S. G. Sprecher, K. Brodetskiy, R. J. Johnston Jr., P. Lidder, N. Vogt, A. Celik, C. Desplan, Feedback from rhodopsin controls rhodopsin exclusion in Drosophila photoreceptors. Nature 479, 108-112 (2011).

26. S. E. Maguire, A. Afify, L. A. Goff, C. J. Potter, A feedback mechanism regulates odorant receptor expression in the malaria mosquito, Anopheles gambiae. bioRxiv, 2020.07.23.218586 (2020).

27. M. Ai, S. Blais, J. Y. Park, S. Min, T. A. Neubert, G. S. Suh, lonotropic glutamate receptors IR64a and IR8a form a functional odorant receptor complex in vivo in Drosophila. J. Neurosci. 33, 10741-10749 (2013).

28. M. Gummalla, S. Galetti, R. K. Maeda, F. Karch, Hox gene regulation in the central nervous system of Drosophila. Front. Cell. Neurosci. 8, 96 (2014).

29. A. J. Durston, Global posterior prevalence is unique to vertebrates: A dance to the music of time? Dev. Dyn. 241, 1799-1807 (2012).

30. F. Port, H. M. Chen, T. Lee, S. L. Bullock, Optimized CRISPR/Cas tools for efficient germline and somatic genome engineering in Drosophila. Proc. Natl. Acad. Sci. U.S.A. 111, -E2976 (2014).

31. X. Zhang, W. H. Koolhaas, F. Schnorrer, A versatile two-step CRISPR- and RMCE-based strategy for efficient genome engineering in Drosophila. G3 4, 2409-2418 (2014)

32. S. J. Gratz, F. P. Ukken, C. D. Rubinstein, G. Thiede, L. K. Donohue, A. M. Cummings, K. M. O'Connor-Giles, Highly specific and efficient CRISPR/Cas9-catalyzed homologydirected repair in Drosophila. Genetics 196, 961-971 (2014).

33. M. Saina, R. Benton, Visualizing olfactory receptor expression and localization in Drosophila. Methods Mol. Biol. 1003, 211 (2013).

34. L. L. Prieto-Godino, A. F. Silbering, M. A. Khallaf, S. Cruchet, K. Bojkowska, S. Pradervand, B. S. Hansson, M. Knaden, R. Benton, Functional integration of "undead" neurons in the olfactory system. Sci. Adv. 6, eaaz7238 (2020).

35. A. Dobin, C. A. Davis, F. Schlesinger, J. Drenkow, C. Zaleski, S. Jha, P. Batut, M. Chaisson, T. R. Gingeras, STAR: Ultrafast universal RNA-seq aligner. Bioinformatics 29, 15-21 (2013).

36. H. Li, B. Handsaker, A. Wysoker, T. Fennell, J. Ruan, N. Homer, G. Marth, G. Abecasis, R. Durbin; 1000 Genome Project Data Processing Subgroup, The sequence alignment/ map format and SAMtools. Bioinformatics 25, 2078-2079 (2009).

37. M. Pertea, G. M. Pertea, C. M. Antonescu, T. C. Chang, J. T. Mendell, S. L. Salzberg, StringTie enables improved reconstruction of a transcriptome from RNA-seq reads. Nat. Biotechnol. 33, 290-295 (2015).

38. X. Mou, D. M. Duncan, E. H. Baehrecke, I. Duncan, Control of target gene specificity during metamorphosis by the steroid response gene E93. Proc. Natl. Acad. Sci. U.S.A. 109, 2949-2954 (2012). 
39. S. Chyb, N. Gompel, Atlas of Drosophila Morphology: Wild-Type and Classical Mutants (Academic Press, 2013).

40. X. Bing, T. Z. Rzezniczak, J. R. Bateman, T. J. S. Merritt, Transvection-based gene regulation in Drosophila is a complex and plastic trait. G3 4, 2175-2187 (2014).

Acknowledgments: We thank E. Baehrecke and C. Doe for reagents, C. Dumayne for help with qRT-PCR experiments, and M. C. Gambetta and members of the Benton laboratory for discussions and comments on the manuscript. Funding: L.L.P.-G. was supported by a FEBS Long-Term Fellowship. T.O.A. was supported by a Human Frontier Science Program Long-Term Fellowship (LT000461/2015-L) and by a Swiss National Science Foundation Ambizione Grant (PZ0OP3 185743). Research in R.B.'s laboratory was supported by the University of Lausanne, European Research Council Consolidator and Advanced Grants (615094 and 833548, respectively), and the Swiss National Science Foundation (310030B_185377). Author contributions: All authors contributed to the experimental design, analysis, and interpretation of results. K.M. performed all experiments, except for those in Fig. 3D and figs. S3 ( $\mathrm{C}$ to $\mathrm{H}$ ) and S5 (B and $\mathrm{C}$ ), as well as RNA isolation for RNA-seq and
qRT-PCR experiments, which were performed by S.C. P.C.C. provided the candidate gene list for the RNAi screen and performed initial analysis of RNA-seq data. L.L.P.-G. supervised K.M. during the initial stages of the project. T.O.A. generated the $I r 75 b$ mutant. S.P. performed RNA-seq data analysis. K.M. and R.B. wrote the paper with input from all other authors. Competing interests: The authors declare that they have no competing interests. Data and materials availability: All data needed to evaluate the conclusions in the paper are present in the paper and/or the Supplementary Materials. RNA-seq data are available in GEO (accession GSE150296). Additional data related to this paper may be requested from the authors.

Submitted 17 August 2020

Accepted 17 June 2021

Published 6 August 2021

$10.1126 /$ sciadv.abe3745

Citation: K. Mika, S. Cruchet, P. C. Chai, L. L. Prieto-Godino, T. O. Auer, S. Pradervand, R. Benton, Olfactory receptor-dependent receptor repression in Drosophila. Sci. Adv. 7, eabe3745 (2021). 